\title{
PENGARUH RANGE OF MOTION (ROM) AKTIF DAN PASIF TERHADAP RENTANG GERAK PADA LANSIA YANG MENGALAMI ARTITIS REMATOID DI KOTA BENGKULU
}

\author{
Septi Andrianti ${ }^{1)}$, Feny Marlena ${ }^{1)}$,Azhari Septiawan ${ }^{2)}$ \\ ${ }^{1}$ Program Studi Keperawatan STIKES Bhakti Husada Bengkulu, \\ ${ }^{2}$ Dinas Kesehatan Provinsi Bengkulu \\ E-mail: andriantisepti@gmail.com
}

\begin{abstract}
Problems: The elderly experience a deterioration in the musculoskeletal system, rheumatoid arthritis is a disease that attacks the joints in the elderly, as a result of this disease the elderly experienced pain so that they are afraid to move which results in confusion and decreased range of motion. One of the interventions that can be done to reduce stiffness and increase the range of motion is Rang of Motion (ROM), both actively and passively. Bengkulu has a significant incidence of rheumatoid arthritis which is increasing every year. The incidence of rheumatoid arthritis in Bengkulu City in 2016 was 1,239 cases and in 2017 was 1,487 cases, and increased in 2018 as many as 1,872 cases. The Aim of The Research:Was to see the effect of active and passive range of motion (ROM) exercises on the range of motion of the elderly with rheumatoid arthritis in Bengkulu City.Research Method: Was a quasy experimental study, using a three-group design with a countrol design, namely the group that was given active ROM, the group that was given passive ROM, and the control group. The sample of the study was 60 elderly with limited time span using consecutive sampling technique.The Results:showed that there was an effect of range of motion carried out in an active and passive manner on the range of motion of the elderly with rheumatoid arthritis in Bengkulu City with a value $<0.005$. Conclusions: Using a regular range of motion 3 times for 4 weeks can increase the degree of range of motion in rheumatoid patients.
\end{abstract}

Keywords:ROM, Rheumatoid Arthritis, Elderly

\begin{abstract}
ABSTRAK
Permasalahan: Lansia mengalami kemunduran pada system musculoskeletal, penyakit artritis rematoid merupakan penyakit yang menyerang persendian pada lansia, akibat dari penyakit tersebut lansia mengalami nyeri sehingga lansia takut melakukan pergerakan yang akan mengakibatkan terjai kekauan dan menurunan pada rentang gerak. Salah satu intervensi yang dapat dilakukan untuk mengurangi kekakuan dan meningkatkan rentang gerak dilakukan Rang of Motion (ROM) baik secara aktif maupun pasif. Bengkulu memiliki angka kejadian artritis rematoid yang cukup signifkan dimana setiap tahunya mengalami peningkatan. Kejadian artritis rematoid di Kota Bengkulu pada tahun 2016 sebanyak 1.239 kasus dan pada tahun 2017 sebanyak 1.487 kasus meningkat pada tahun 2018 sebanyak 1.872 kasus. Tujuan Penelitian: untuk mengetahui pengaruh latihan range of motion (ROM) yang dilakukan secara aktif dan pasif terhadap rentang gerak pada lansia yang mengalami artritis rematoid di Kota Bengkulu. Metode Penelitian: Penelitian ini dengan Quasy experimental dengan menggunakan rancangan three group with countrol design yaitu kelompok yang diberikan ROM aktif, kelompok yang diberikan ROM pasif dan kelompok kontrol. Sampel penelitian yaitu lansia yang mengalami keterbatasan rentang gerak pada lutut sebanyak 60 lansia dengan teknik consecutive sampling. Hasil: Hasil penelitian yaitu terdapat pengaruh range of motion yang dilakukan cara aktif, pasif terhadap rentang gerak pada lansia yang mengalami artritis rematoid di Kota Bengkulu dengan $\mathrm{p}$ vaue $<0,005$. Kesimpulan:range of motion yang dilakukan secara teratur seminggu 3 kali selama 4 minggu dapat meningkatkan derajad rentang gerak pada penderita artritis rematoid.
\end{abstract}

Kata kunci: ROM, Artritis Rematoid, Lansia 


\section{PENDAHULUAN}

Lansia merupakan proses tahapan akhir dari penuaan. Lansia merupakan periode penutup rentang kehidupan yaitu dimana seseorang telah beranjak jauh dari periode terdahulu yang lebih menyenangkan atau beranjak dari waktu yang penuh dengan manfaaat. Usia 60 tahun dipandang sebagai garis pemisah antara usia madya dengan lanjut. Usia 65 sebagai usia pensiun dalam berbagai urusan dan dianggap sebagai tanda dimulainya usia lanjut (Hurlock,2012).

Berdasarkan data Perserikaan Bangsa-bangsa (PBB) tentang World Population Ageing, diperkirakan pada tahun 2015 terdapat 901 juta jiwa penduduk lanjut usia di dunia. Jumlah tersebut diproyeksikan terus meningkat mencapai 2 (dua) miliar jiwa pada tahun 2050 (UN, 2015).Seperti halnya yang terjadi di negara-negara di dunia, Indonesia juga mengalami penuaan penduduk. Tahun 2019, jumlah lansia Indonesia diproyeksikan akan meningkat menjadi 27,5 juta atau 10,3\%, dan 57,0 juta jiwa atau 17,9\% pada tahun 2045 (BPS, Bappenas, UNFPA, 2018). Hal ini menunjukkan konsistensi pertambahan jumlah penduduk lansia dari waktu ke waktu (Kemenkes RI, 2017).

Saat ini jumlah lansia di seluruh dunia 629 juta jiwa dan pada tahun 2025 diperkiraka mencapai 1,2 miliar. Lansia mengalami dampak perubahan epidemiologis, penyakit pada lanjut usia cenderung ke arah penyakit degenerative (Bell, 2014). Masalah kesehatan pada lansia pada system musculoskeletal yaitu penyakit artritis rematoid. Artritis Rematoid ditandai dengan adanya peradangan dari lapisan selaput sendi (sinovium) yang mana menyebabkan sakit, kekauan,hangat,bengkak dan merah. Peradangan sinovium dapat menyerang dan merusak tulang serta kartilago. Sel penyebab radang melepaskan enzim yang dapat mencerna tulang dan kartilago. Sehingga dapat terjadi kehilangan bentuk dan kelurusan pada sendi, yang menghasilkan rasa sakit dan pengurangan kemampuan bergerak (Nasution, 2017).

Pada lansia kekuatan pada otot mulai merosot, dengan kemunduran yang dipercepat setelah usia 60 tahun. Dari 10 sampai 15\% kekuatan otot dapat hilang setiap minggu jika otot beristirahat sepenuhnya, dan sebanyak 5,5\% dapat hilang setiap hari pada kondisi istirahat dan imobilitas sepenuhnya (Stanley dan Beare, 2016). Jenis latihan yang dianjurkan bagi lansia adalah latihan isotonik (Mudrikhah, 2012). Latihan isotonik menyebabkan kontraksi otot, perubahan panjang otot dan merangsang aktivitas osteoblastik (aktivitas sel pembentuk otot). Latihan ini juga meningkatkan tonus otot, massa dan kekuatan otot serta mempertahankan fleksibilitas sendi, rentang pergerakan dan sirkulasi (Potter \& Perry, 2010). Latihan ROM merupakan latihan isotonik yang bermanfaat untuk meningkatkan kekuatan 
otot, mencegah memburuknya kapsul sendi, ankiolosis, dan kontraktur sendi (Kozier\&Erb, 2009). Latihan gerak sendi dengan ROM adalah latihan yang memungkinkan terjadinya kontraksi dan pergerakan otot, dimana klien menggerakkan masing-masing persendiannya sesuai gerakan normal baik secara aktif ataupun pasif.

Latihan ROM aktif yaitu latihan isotonic yang mampu mempertahankan atau meningkatkan kekuatan dan daya tahan otot serta dapat mencegah perburukan kapsul sendi, ankilosis, dan kontraktur. Pada sendi lutut lansia sebanyak 25\% mengalami kekakuan pada posisi fleksi. Kekakuan tersebut dapat disebabkan adanya kalsifikasi pada lansia yang akan menurunkan fleksibilitas sendi (Uliya, Soempeno, dan Kushartanti, 2011).Bengkulu memiliki angka kejadian artritis rematoid yang cukup signifkan dimana setiap tahunya mengalami peningkatan. Kejadian artritis rematoid di Kota Bengkulu pada tahun 2016 sebanyak 1.239 kasus dan pada tahun 2017 sebanyak 1.487 kasus meningkat pada tahun 2018 sebanyak 1.872 kasus.

Lansia mengalami kemunduran pada system musculoskeletal, penyakit artritis rematoid merupakan penyakit yang menyerang persendian pada lansia, akibat dari penyakit tersebut lansia mengalami nyeri sehingga lansia takut melakukan pergerakan yang akan mengakibatkan terjai kekauan dan menurunan pada rentang gerak. Salah satu intervensi yang dapat dilakukan untuk mengurangi kekakuan dan meningkatkan rentang gerak dilakukan Rang of Motion (ROM) baik secara aktif maupun pasif. Berdasarkan studi pendahulu diketahui bahwa dari 5 orang lansia yang mengalami artritis rematoid terdapat 3 orang mampu melakukan ROM secara aktif dan 2 orang lansia mampu melakukan ROM pasif.

\section{METODE PENELITIAN}

Penelitian ini merupakan penelitian kuantitatif dengan Quasy experimental dengan menggunakan rancangan three group with countrol design. Dalam rancangan ini, terdapat tiga kelompok yaitu kelompok yang diberikan ROM aktif, kelompok yang diberikan ROM pasif dan kelompok kontrol. Dimana setiap kelompok diawali dengan pra-test dan setelah pemberian perlakuan selesai dilakukan post-test.

Populasi penelitian seluruh lansia yang mengalami keterbatasan rentang gerak pada lutut dan ankle yang berada di Kota Bengkulu sebanyak 60 lansia yang terdiri dari 3 kelomok yaitu 20 kelompok kontrol, 20 yang diberikan ROM aktif, 20 orang yang diberikan ROM secara pasif dengan kriteria inklusi ; berjenis kelamin perempuan, lansia usia 60-74 tahun, lansia yang mengalami keterbatasan gerak/ memiliki masalah pada sisitem musculoskeletal, 
lansia yang aktif mengikuti ROM, lansia yang tidak mengalami kelumpuhan serta kontraktur pada persendian, dan bersedia mengikuti latihan ROM secara teratur.

Penelitian ini dilakukan di Kota Bengkulu selama 4 minggu dengan latihan ROM satu kali dalam sehari dan 3 kali dalam seminggu. Yang dilaksanakan mulai tanggal 18 Agustus 18 September 2020. Instrumen Penelitian menggunakan alat ukur berupa goneometer untuk mengukur rentang gerak.

\section{HASIL}

Tabel 1. Distribusi Rata - Rata Rentang Gerak Pada Sendi Lutut Sebelum dan Setelah Dilakukan Range of Motion Pada Kelompok Kontrol $(\mathrm{n}=20)$

\begin{tabular}{lrrrc}
\hline \multirow{2}{*}{ Rentang Gerak } & \multicolumn{2}{c}{ Mean } & \multicolumn{2}{c}{ SD } \\
\cline { 2 - 5 } & 103,17 & 104,92 & 5,113 & 5,482 \\
\hline Fleksi Lutut Kanan & 104,68 & 104,88 & 5,244 & 4,666 \\
Fleksi Lutut Kiri & 103,93 & 104,13 & 4,833 & 4,890 \\
Ekstensi Lutut Kanan & 102,45 & 103,11 & 4,690 & 4,400 \\
Ekstensi Lutut Kiri & & & & \\
\hline
\end{tabular}

Berdasarkan tabel 1 diatas diketahui bahwa terdapat perbedaan rata - rata rentang gerak pada sendi lutu pre test dan post test pada kelompok kontrol. Pada senidi lutut fleksi lutut kanan nilai pre test yaitu $103,17^{0}$ dan setelah hari 4 minggu dilakukan pengukuran kembali terjadi peningkatan pada derajad rentang gerak sebesar $1,75^{\circ}$. Hal serupa juga terjadi pada fleksi lutut kiri pada lansia yang mengalami atritis rematoid. Pre test pada fleksi lutut kiri sebesar $104,68^{0}$ meningkat pada minggu ke 4 sebesar $0,2^{0}$ menjadi $104,88^{0}$. Pada perlakuan ekstensi lutut kanan pada minggu pertama pre test sebesar $103,93^{0}$ dan pada mingu ke-4 meningkat menjadi $104,13^{\circ}$. Sedangkan pada ekstensi lutut kiri derajad rentang gerak pada lansia sebesar $102,45^{\circ}$ dan pada minggu ke-4 meningkat menjadi $103,11^{0}$.

Tabel 2. Distribusi Rata - Rata Rentang Gerak Pada Sendi Lutut Sebelum dan SetelahDilakukan Range of Motion Secara Aktif $(\mathrm{n}=20)$

\begin{tabular}{lcccc}
\hline \multirow{2}{*}{ Rentang Gerak } & \multicolumn{2}{c}{ Mean } & \multicolumn{2}{c}{ SD } \\
\cline { 2 - 5 } & Pre & Post & Pre & Post \\
\hline Fleksi Lutut Kanan & 107,17 & 111,32 & 5,353 & 5,492 \\
Fleksi Lutut Kiri & 104,48 & 109,08 & 5,544 & 5,766 \\
Ekstensi Lutut Kanan & 105,53 & 109,42 & 4,623 & 4,630 \\
& & & & \\
& Septi Andrianti, Feny Marlena,Azhari Septiawan & 141 \\
\hline
\end{tabular}


Dari tabel diatas diperoleh keterangan bahwa rata - rata rentang gerak yang dapat dihasilkan oleh gerakan ROM secara aktif pada sendi lutu (fleksi)sebelum diberi latihan range of motion secara aktif adalah $107,17^{0}$ dengan simpangan baku 5,353 dan rentang gerak yang dapat dihasilkan oleh gerakan pada sendi lutut setlah diberi latihan range of motion secara aktif adalah $111,32^{\circ}$ dengan simpangan baku 5,492. Pada lutut kiri juga didapatkan hasil bahwa terdapat perubahan pada rentang gerak sebelum dan setelah yaitu sebelum dilakukan ROM fleksi lutut kiri sebesar $104,48^{\circ}$ dan setelah dilakukan ROM selama 4 minggu terdapat peningkatan menjadi $109,08^{0}$.

Pada tabel 2 juga didapatkan hasil bahwa pada gerakan ekstensi lutut kanan sebesar $105,53^{\circ}$ dan post test sebesar $109,42^{\circ}$ dengan standar deviasi sebelum 4,623 dan setelah 4,630. Pada ekstensi lutut kiri derajad gerakan sendi lutut sebesar $104,55^{\circ}$ dan setelah menjadi $110,61^{0}$ dengan standar deviasi pre 5,430 dan post 4,450 .

Tabel 3. Distribusi Rata - Rata Rentang Gerak Pada Sendi Lutut Sebelum danSetelah Dilakukan Range of Motion Secara Pasif $(n=20)$

\begin{tabular}{lcccc}
\hline \multirow{2}{*}{\multicolumn{1}{c}{ Rentang Gerak }} & \multicolumn{2}{c}{ Mean } & \multicolumn{2}{c}{ SD } \\
\cline { 2 - 5 } & Pre & Post & Pre & Post \\
\hline Fleksi Lutut Kanan & 103,27 & 105,32 & 4,543 & 4,872 \\
Fleksi Lutut Kiri & 102,38 & 105,48 & 4,664 & 4,896 \\
Ekstensi Lutut Kanan & 104,23 & 104,52 & 4,763 & 4,870 \\
Ekstensi Lutut Kiri & 103,45 & 105,43 & 5,460 & 5,850 \\
\hline
\end{tabular}

Gerakan sendi lutut (fleksi kanan) sebelum diberi latihan range of motionsecaa pasif adalah $103,27^{0}$ dengan derajad deviasi 4,543. Sudut maksimum yang dapat dihasilkan oleh gerakan sendi lutut kanan setelah diberi latihan range of motion adalah 105,32 dengan standar deviasi 4,872. Gerakan sendi lutut (fleksi kiri)sebelum diberi latihan range of motion adalah $102,38^{\circ}$ dengan standar deviasi 4,664. Sudut maksimum yang dapat dihasilkan oleh gerakan sendi lutut kiri setelah diberi latihan range of motion adalah $105,48^{0}$ dengan standar deviasi 4,896 .

Pada tabel 3 dapat diketahui bahwa gerakan sendi lutut (ekstensi lutut kanan) sebelum diberi latihan range of motionsecaa pasif adalah $103,23^{\circ}$ dengan derajad deviasi 4,763 . Sudut maksimum yang dapat dihasilkan oleh gerakan sendi ekstensi lutut kanan setelah diberi latihan range of motion adalah $104,52^{\circ}$ dengan standar deviasi 4,870. Gerakan sendi lutut 
(Ekstensi lutut kiri)sebelum diberi latihan range of motion adalah $103,45^{\circ}$ dengan standar deviasi 5,460. Sudut maksimum yang dapat dihasilkan oleh gerakan sendi ekstensi lutut kiri setelah diberi latihan range of motion adalah 105,43 dengan standar deviasi 5,850.

Tabel 4.Pengaruh Range of Motion Yang Dilakukan Secara Aktif dan Pasif Pada Lansia Yang Mengalami Artritis Rematoid Di Kota Bengkulu Tahun 2020.

\begin{tabular}{lccc}
\hline Rentang Gerak & \multicolumn{3}{c}{ Sig } \\
\cline { 2 - 4 } & Kontrol & ROM Aktif & ROM Pasif \\
\cline { 2 - 4 } Fleksi Lutut Kanan & 0,003 & 0,001 & 0,001 \\
Fleksi Lutut Kiri & 0,001 & 0,001 & 0,001 \\
Ekstensi Lutut Kanan & 0,001 & 0,001 & 0,001 \\
Ekstensi Lutut Kiri & 0,001 & 0,002 & 0,001 \\
\hline
\end{tabular}

Pada tabel 4 diketahui bahwa berdasarkan hasil uji statistic dengan menggunakan paired sampel t- test pada kelompok kontrol, ROM aktif dan ROM pasif pada gerakan fleksi lutut kanan dan lutut kiri serta pada gerakan ekstensi lutut kanan dan lutut kiri didapatkan hasil $\mathrm{p}$ value $<0,005$. Pada kelompok kontrol uji statistic didapatkan nilai $\mathrm{p}$ pada fleksi lutut kanan 0,003, fleksi lutut kiri sebesar 0,001, ekstensi lutut kanan nilai p 0,001 dan ekstensi lutut kiri 0001.

Hasil perlakuan pada kelompok ROM aktif didapatkan nilai p value pada gerakan fleksi lutut kanan 0,001, fleksi lutut kiri 0,001, ekstensi lutut kanan 0,001 serta ekstensi lutut kiri 0,002. Artinya terdapat pengaruh ROM aktif terhadap rentang gerak pada lansia yang mengalami artritis rematoid di Kota Bengkulu. Hal serupa juga terjadi pada kelompok ROM pasif dimana terdapat nilai p pada gerakan fleksi lutut kanan sebesar 0,001, fleksi lutut kiri 0,001, gerakan ekstensi lutut kanan 0,001 serta ekstensi lutut kiri 0,001.

\section{PEMBAHASAN}

Hasil penelitian yang dilakukan pada kelompok lansia yang mengalami artritis rematoid di Kota Bengkulu yang dilakukan ROM aktif dan pasif selama 4 minggu dengan frekuensi 3 kali seminggu didapatkan hasil terjadi peningkatan derajad rentang gerak pre test dan post test. Pada ROM yang dilakukan secara aktif terjadi perubahan derajad rentang gerak pada sendi lutut (fleksi) sebelum $107,17^{0}$ dan post $111,32^{\circ}$ dengan selisi 4,15 . Pada lutut kiri juga didapatkan hasil bahwa terdapat perubahan pada rentang gerak sebelum dan setelah yaitu sebelum $104,48^{0}$ dan setelah $109,08^{0}$. Hal serupa juga erjadi pada gerakan ekstensi lutut kanan sebesar $105,53^{\circ}$ dan post test sebesar $109,42^{\circ}$. Pada ekstensi lutut kiri $104,55^{\circ}$ dan setelah $110,61^{\circ}$. Adanya peningkatan pada rentang gerak sendi lutut yang dilakukan ROM secara aktif dapat tejadi karena adanya pergerakan pada serat otot. Adanya pengaruh latihan 
ROM yang dilakukan secara aktif terhadap rentang gerak pada lansia yang mengalami artritis rematoid dapat dibuktikan dengan uji statistic $\mathrm{p}<0,05$. Latihan ROM yang dilakukan secara continue sesuai dengan prosedur dapat meningkatkan kekuatan otot pada sendi lutut lansia sehingga akan memperluas pergerakan pada sendi lutut lansia baik secara fleksi maupun ekstensi.

Adanya pengaruh latihan range of motionaktif pada pretest dan posttest yaitu adanya peningkatan kelentukan sendi lutut lebih tinggi. Hal ini terkait dengan pemberian latihan range of motionyang menyebabkan peningkatan kelentukan sendi panggul dan sendi lutut. Dimana latihan range of motion aktif dapat meningkatkan luas gerak sendi. Hasil penelitian ini didukung penelitian Mundrikah, Sudaryanto, Kartinah (2012) tentang Pengaruh Latihan Range Of MotionAktif Terhadap Peningkatan Rentang Gerak Sendi Dan Kekuatan Otot Kaki Pada Lanjut Usia Di Panti Wreda Dharma Bakti Surakarta, penelitian ini menunjukkan bahwa ada peningkatan signifikan pada rentang gerak sendi lutut dan ankleserta peningkatan pada kekuatan otot lansia setelah diberikan range of motion.

Peningkatan rentang gerak juga terjadi pada kelompok yang diberikan ROM secara pasif, dimana setelah dilakukan ROM secara pasif pada lansia yang mengalami gangguan pergerakan selama 4 minggu terdapat nilai rata - rata rentang gerak (fleksi dan ekstensi) sebelum dilakukan ROM secara pasif yaitu fleksi dan ekstensi lutut kanan $\left(103,27^{0}\right.$ dan $\left.104,23^{0}\right)$, fleksi dan ekstensi lutut kiri $\left(102,38^{0}\right.$ dan $\left.103,45^{\circ}\right)$. Dan setelah diberikan ROM pasif rentang gerak (fleksi dan ekstensi) fleksi dan ekstensi lutut kanan $\left(105,32^{0}\right.$ dan $\left.104,52^{0}\right)$, fleksi dan ekstensi lutut kiri $\left(105,48^{0}\right.$ dan $\left.105,43^{\circ}\right)$. Hasil ini juga didapatkan bahwa terdapat pengaruh terapi ROM pasif terhadap rentang gerak pada lansia yang mengalami artritis rematoid dengan $\mathrm{p}$ value $<0,005$. Hasil tersebut menunjukkan bahwa latihan ROM selama 4 minggu sudah dapat meningkatkan ROM fleksi sendi lutut pada lansia yang mengalami keterbatasan gerak. Akibat penyakit artritis rematoid.

Hasil peneltian ini sesuai dengan penelitian Soempeno, dkk (2011) tentang Pengaruh Latihan Range Of Motion (ROM) pasif Terhadap Fleksibilitas Sendi Lutut pada Lansia. Penelitian ini menunjukkan bahwa ada peningkatan yang signifikan antara pengukuran re test dan post test pada fleksi lutut kanan dan kiri. Adanya pergerakan pada persendian akan menyebabkan terjadinya peningkatan aliran darah kedalam kapsula sendi dan memberikan nutrisi yang memungkinkan tulang untuk bergerak dengan lancar dan tanpa rasa sakit atau ketidaknyamanan (Jenkins, 2015).

Latihan ROM pasif terbukti tidak hanya meningkatkan rentang gerak tetapi juga dapat mempertahankan rentang gerak. Hal ini terlihat dari hasil penelitian yang menunujukkan 
bahwa padapre testdanpost testterlihat rata-rata rentang gerak sendi lutut lansia mengalami peningkatan.Jika terjadi penurunan gerak atau mobilitas maka aliran darah berkurang, sendi menjadi kaku dan menyakitkan, hal ini menyebabkan penurunan aktivitas dan pada akhirnya rentang gerak akan semakin mengalami penurunan dan keterbatasan gerak (Jenkins, 2015).

Latihan Range of Motion (ROM) pasif adalah latihan ROM yang dilakukan oleh lansia dengan bantuan peneliti dari setiap gerakan yang dilakukan. Indikasi latihan pasif adalah semua lansia yang tidak mampu melakukan ROM sendiri dan kooperatif. Manfaat darilatihan ROM pasif memperbaiki tonus otot, meningkatkan mobilisasi sendi, memperbaiki toleransiotot untuk latihan, meningkatkan massaotot dan mengurangi kehilangan tulang.

Adanya peningkatan rentang gerak pada kelompok kontrol dapat terjadi karena adanya aktivitas yang dilakukan oleh lansia sehari hari, seperti berjalan, duduk, dan lain sebagainya. Adanya keterbatasan dalam pergerakan dapat disebabkan oleh beberapa hal yaitu faktor usia dan jenis kelamin dan lama penyakit. Selain itu pada penelitian ini responden telah mengalami penyakit artritis rematoid lebih dari 4 tahun, yang artinya lansia telah mengalami keterbatasan gerak akibat nyeri yang terjadi sudah cukup lama sehingga mobilisasi yang dilakukan oleh subyek hanya duduk dan berjalan disekitar kamar tidur, ruang tengah, teras, ke kamar mandi untuk buang air kecil dan besar serta tidak pernah mengikuti kegiatan atau latihan yang dapat meningkatkan mobilitasnya. Akibat dari pergerakan berkurang, maka persendian menjadi lebih kaku, terasa nyeri dan akan mengurangi ROM sampai mengurangi kemampuan beraktivitas.

Debora (2019) menyatakan bahwa seseorang dengan gangguan fungsi motoric harus melakukan rehabiliatif secepatnya agar fungsi motorik atas bisa segera pulih. Salah satu upaya yang dilakukan untuk pemulihan yaitu pemberian latihan seperti mobilisasi (ROM) baik secara pasif maupun aktif. Hal serupa juga diungkapkan oleh Adek (2020) yang menyatakan bahwa penatalaksanaan nonfarmakologi bagi penderita artritis rematoid dapat dilakukan dengan melakukan latihan fisik ringan seperti latihan rentang gerak sendi (ROM) yang dapat mengurangi nyeridan terbukti setelah dilakukan ROM nyeri mengalami penurunan. Berdasarkan penelitian yang dilakukan Rahmiati dan Afrianti (2018) di Aceh menunjukkan ada pengaruh latihan ROM terhadap nyeri sendi pada lansia. Menurut Widyasih, Nian dan Widhianto (2019) yang melakukan penelitian ekperiman pada lansia dengan diberi latihan Stretching ROM selama 7 kali selama 7 hari menunjukkan bahwa dapat menurunkan nyeri sendi pada lansia dengan Gout

Beberapa tujuan mobilisasiRange Of Motion (ROM) yaitu mempertahankan atau memelihara fleksibilitas dan kekuatan otot, memelihara mobilitas persendian dan mencegah 
kelainan bentuk, kekakuan dan kontraktur. Nilai rentang gerak yang meningkat tersebut juga memberi jawaban pada manfaat Range Of Motion (ROM) yaitu memperbaiki tonus otot, meningkatkan mobilisasi sendi, dan memperbaiki toleransi otot untuk latihan. Latihan Range of Motion (ROM) merupakan salah satu bentuk latihan dalam proses rehabilitasi yang dinilai masih cukup efektifuntuk mencegah terjadinya kecacatan pada pasien dengan stroke.

Menurut Ambardini (2013) menyatakan bahwa manfaat Range Of Motion Excercise adalah mobilitas sendi dan memperkuat otot yang menyokong dan melindungi sendi, mengurangi nyeri dan kaku sendi, serta dapat mengurangi pembengkakan. Hal ini diperkuat oleh hasil penelitian Harus (2020) yang menyatakan adanyaperbedaan antara perubahankekuatanotot untukpre testdanposttestdan perbedaan tersebutsetelah diuji menggunakan ujiwilcoxon didapatkan nilai $\rho$-value $=0,000$ yangartinya $\rho$-value $<0,05$. Penelitian Rianti (2019) terdapat perbedaanyang signifikanderajat kekuatan otot sebelum terapi ROM, sebelum dilakukan terapi ROM derajatkekuatanototpasien termasuk kategori derajat1(hanya berupa perubahantonus)hingga derajat 3(mampumenggerakan sendi, dapat melawangravitasi, tidak kuat terhadap tahanan). Maruli (2018) yang menyatakan bahwa berdasarkan hasil penelitian diketahui terdapat pengaruh Range Of Motionterhadap skala nyeri sendi pada lansia dengan osteoartritis kneedengan $\mathrm{p}$ value $0,000(\alpha<0,05)$. Dipa (2020) terdapat pengaruh positif pemberian Range Of Motion Excercise untukmenurunkan nyeri sendi pada lansia dengan OsteoartritisKneediUPT Puskesmas NgawiPurba.

\section{KESIMPULAN}

Hasil penelitian ini di simpulkan terdapat pengaruh range of motion yang dilakukan cara aktif, pasif terhadap rentang gerak pada lansia yang mengalami artritis rematoid di Kota Bengkulu dengan $\mathrm{p}$ value $<0,005$.

\section{UCAPAN TERIMA KASIH}

Dalam melaksanakan penelitian ini, peneliti mengucapkan terima kasih kepada Kepada Dirjen Kementrian Riset dan Teknologi Atas Bantuan Dana Hibah Bagi Penelitian Dosen Pemula Tahun Anggaran 2019.Peneliti juga mengucapkan terima kasih kepada Kepala Dinas Kesehatan Provinsi Bengkulu, Kepala Dinas Kesehatan Kota Bengkulu, Kepala Puskesmas dan Panti Tresna Werdah Kota Bengkulu. 


\section{DAFTAR PUSTAKA}

Adek, Suci Ramadhani. 2020.asuhan keperawatan keluarga pada lansia ny. $N$ dengan kasus asam urat serta penerapan latihan rentang gerak sendi (rom) untuk menurunkan nyeri sendi di rw 5 kelurahan jati kecamatan padang timur. Diploma thesis, Universitas Andalas. http://scholar.unand.ac.id/id/eprint/59292

Arif, M. 2010. Kapita Selekta Kedokteran. Jilid 2. Edisi III. Jakarta: Penerbitan Media Aesculapius FKUI

Azizah. 2011. Keperawatan Lanjut Usia. Yogyakarta: Graha Ilmu

Begg, R.K. \& Sparrow, W.A. 2006. Ageing Effects on Knee and Ankle Joint Angles at Key Events and Phases of The Gait Cycle. Journal of Medical Engineering \& Technology.30.6.

Bell, Petrus Andriyanto. 2014. Pengaruh Latihan ROM Terhadap Intesitas Nyeri Lutut Pada Lansia Yang Mengalami Osteoartritis. Skripsi. Universitas Katolik Widya Mandala Surabaya.

Dahlan, M.S. 2011. Statistik Untuk Kedokteran Dan Kesehatan. Jakarta: Salemba Medika.

Dipa Yuli Siswanto. 2020. Pengaruh Range Of Motion Excerciseuntuk Menurunkan Nyeri Sendi Lutut Pada Lansia Dengan Osteoarthritis Knee Di Upt Puskesmas Ngawi Purba Kabupaten Ngawi. Fakultas Ilmu Kesehatan Universitas Muhammadiyah Surakarta. Skripsi.

Harun AlRasid, JuliantoLaia, Ratih Suryaman,Retno DwiSanti. 2020. Pengaruh Range Of Motion (Rom) Terhadap KekuatanOtotPasienPasca Stroke. Jurnalllmiah Wijaya Volume 12 Nomor1,Maret2020Hal1 -11;website:www.jurnalwijaya.com;p-ISSN: 2301-4113; e-ISSN: 2723-344812

Hoppenfeld, S., \& Murthy, V.L. 2011. Terapi dan Rehabilitasi Fraktur. New York : Lippincott Williams \& Wilkins

Hurlock, E. B. 2012. Psikologi Perkembangan Suatu Pendekatan Sepanjang Rentang Kehidupan (Alih Bahasa Istiwidayanti dkk. Edisi Ke lima. Jakarta : Erlangga

Kemenkes RI. 2013. RISKESDAS. Jakarta: Kemenkes RI.

Kemenkes RI.2017. Analisis Lansia Di Indonesia.

Kozier \& Erb. 2009. Buku Ajar Praktek Keperawatan Klinis Edisi 5.EGC : Jakarta

Liza Puspa Dewi, Maria Astrid, Sudibyo Supardi. 2020. Analisis Pengaruh Latihan Rentang Gerak Terhadap Peningkatan Kekuatan Otot Dan Aktivitas Perawatan Diri Pasien Stroke Di RSUD Kota Depok.

Maryam. 2010. Mengenal Usia Lanjut dan Perawatannya. Jakarta : Salemba Medika

Mudrikhah. 2012. Pengaruh Latihan Range Of Motion Aktif Terhadap Peningkatan Rentang Gerak Sendi Dan Kekuatan Otot Kaki Pada Lansia Di Panti Wreda Dharma Bakti Surakarta. Universitas Muhammadiyah Surakarta

Muttaqin, 2010. Pengkajian Keperawatan: Aplikasi Pada Praktik Klinik. Jakarta: Salemba Medika

Nasution SK, Juliana S. 2017. Pengaruh Teknik Relaksasi Otot Progresif Terhadap Nyeri Pasien Rheumatoid Artritis di Wilayah Kerja Puskesmas Darussalam Medan. Akademia Vol. 21 No. 3

Notoatmodjo, S. 2010. Metodologi Penelitian Kesehatan. Jakarta: Rineka Cipta.

Nurarif .A.H. dan Kusuma. H. 2015. Asuhan Keperawatan Berdasarkan Diagnosa Medis \& NANDA NIC-NOC. Jogjakarta: MediAction

Potter dan Perry. 2010. Buku Ajar Fundamental Keperawatan. Jakarta : EGC.

Pudjiastuti, S.S. \& Utomo, B. 2013. Fisioterapi Pada Lansia. Jakarta: EGC

Rahayu, L. P. et al (2019) 'The Risk Factor of Recurrence Stroke among Stroke and Transient Ischemic Attack Patients in Indonesia', KnE Life Sciences, 2019, pp.87-97 
Rini Debora Silalahi 2019. Peran Perawat Dalam Tingakan Rehabilitatif Pasien Pasca troe Di Rumah Sakit. Fakultas Keperawatan Universitas Sumatera Utara.

Stanley dan Beare. 2016. Buku Ajar Keperawatan Gerontik. Jakarta : EGC

Suratun. 2011. Klien Gangguan Sistem Muskuloskeletal, Seri Asuhan Keperawatan Cetakan II. JakartA: EGC.

Uliya, S., Soempeno, B., \& KushartantiB.M.W. 2011. Pengaruh Latihan Range Of Motion (ROM) Terhadap Fleksibilitas Sendi Lutut Pada Lansia Di Panti Wreda Wening Wardoyo Ungaran. Jurnal Media Ners. 1.2. 72-78 